\title{
Олег Березюк
}

\section{ОПТИМІЗАЦІЯ МІЖПРЕДМЕТНИХ ЗВ' ЯЗКІВ ПРИ ФОРМУВАННІ КОМПЕТЕНЦІЙ 3 БЕЗПЕКИ У ФАХІВЦІВ РАДІОТЕХНІЧНОГО ПРОФІЛЮ}

До підготовки майбутніх фахівців необхідно підходити не лише з позиції забезпечення їхнього власного професійного та особистісного зростання, а й їхньої готовності забезпечити безпеку життєдіяльності в навколишньому середовищі (Кремечек, 2006). Тому при підготовці майбутніх фахівців радіотехнічного профілю у Вінницькому національному технічному університеті викладаються зокрема такі нормативні дисципліни, що вносяться в навчальні плани як дисципліни обов' язкового вибору «Безпека життєдіяльності» (БЖД) та «Основи охорони праці» (ООП) («Типова навчальна», 2011a; «Типова навчальна», 2011b; Березюк, \& Лемешев, 2011; Березюк, Лемешев, Заюков, \& Королевська, 2017; Кобилянський, Лемешев, \& Березюк, 2010; Лемешев, \& Березюк, 2007), використовуючи комп'ютерні технології навчання та перевірки знань (Березюк, Лемешев, \& Віштак, 2014; Березюк, 2016, 2017а). В різні навчальні роки послідовність викладання дисциплін БЖД та ООП була різною: до 2012/2013 н. р. включно вказані дисципліни вивчались паралельно в одному семестрі, в 2013/2014 - 2016/2017 н. р. спочатку вивчалась дисципліна БЖД, а в наступному семестрі - ООП, в 2017/2018 н. р. спочатку вивчалась дисципліна ООП, а в наступному семестрі - БЖД. Тому актуальною задачею $є$ визначення оптимальної послідовності викладання дисциплін безпека життєдіяльності та основи охорони праці під час підготовки фахівців радіотехнічного профілю.

Під час навчання в університеті, студент засвоює не лише монопредметні знання, а у його свідомості формується система знань, умінь, навичок і компетенцій з різних навчальних дисциплін (Ковальчук, \& Когут, 2008). Кобилянським (2009) проведено дослідження міжпредметних зв'язків безпеки життєдіяльності з основними фаховими дисциплінами при підготовці бакалаврів економічного спрямування, а також наголошено, що відсутність міждисциплінарних зв'язків призводить до значних повторів у навчальних програмах, не відповідає вимогам та реаліям сьогодення і набуває особливої ваги й турботи у зв'язку з перспективами приєднання національної освіти до Болонського процесу. Міжпредметні зв'язки на уроках охорони праці в професійно-технічних закладах освіти під час освоєння професії «Верстатник широкого профілю» досліджені Шукалюк (2016). Хом'юк (2012) досліджено міжпредметні зв'язки при підготовці майбутніх інженерівмашинобудівників. Визначення рівня міжпредметних зв'язків у процесі вивчення біології та географії майбутніми фахівцями у сфері кооперації проведено Л. Березюк та О. Березюком (2018). Березюком (2017b) досліджено міжпредметні зв'язки у процесі вивчення дисциплін циклу безпеки життєдіяльності майбутніми фахівцями радіотехнічного профілю. Однак конкретних досліджень із визначення оптимальної послідовності викладання дисциплін «Безпека життєдіяльності» та «Основи охорони праці» під час підготовки фахівців радіотехнічного профілю, в результаті аналізу відомих публікацій, не було виявлено.

Метою роботи є визначення оптимальної послідовності викладання дисциплін «Безпека життєдіяльності» та «Основи охорони праці» під час підготовки фахівців радіотехнічного профілю.

\section{Результати дослідження}

Визначення оптимальної послідовності викладання дисциплін БЖД та ООП під час підготовки фахівців радіотехнічного профілю за критерієм міцності міжпредметних зв'язків вказаних дисциплін.

Наявність міжпредметних зв'язків між дисциплінами циклу БЖД та ООП визначаємо за успішністю студентів радіотехнічного профілю, які навчались у Вінницькому національного технічному університеті в різні навчальні роки за різних варіантів послідовності викладання вказаних дисциплін. Дослідження проводились окремо в двох академічних групах з різним рівнем успішності, де студенти отримали оцінки за 100-бальною шкалою з різних дисциплін, які наведені в табл. 1-6.

Обробка результатів досліджень проводилась за методикою, описаною Кобилянським (2009).

Подібність дисперсій різних вибірок перевірялась за критерієм Фішера (Немов, 1998). Порівняння однорідності різних вибірок та належності їх до однієї генеральної сукупності (майбутні фахівці радіотехнічного профілю) проводилось за критерієм Стьюдента (Власов, 2002). 
Таблиця 1 - Оцінки студентів 1-ої академічної групи під час вивчення дисциплін БЖд та ООП паралельно в одному семестрі

\begin{tabular}{|c|c|c|c|c|c|c|c|c|c|c|c|c|c|c|c|c|c|c|}
\hline Дисципліна & 1 & 2 & 3 & 4 & 5 & 6 & 7 & 8 & 9 & 10 & 11 & 12 & 13 & 14 & 15 & $\Sigma$ & $\bar{a}$ & $\bar{S}^{2}$ \\
\hline БЖД & 83 & 83 & 79 & 78 & 66 & 66 & 82 & 82 & 75 & 73 & 80 & 68 & 73 & 86 & 72 & 1146 & 76,4 & 39,7 \\
\hline ООП & 80 & 80 & 81 & 66 & 65 & 65 & 75 & 82 & 80 & 82 & 75 & 65 & 73 & 79 & 66 & 1114 & 74,3 & 45,5 \\
\hline
\end{tabular}

Таблиця 2 - Оцінки студентів 2-ої академічної групи під час вивчення дисциплін БЖД та ООП паралельно в одному семестрі

\begin{tabular}{|c|c|c|c|c|c|c|c|c|c|c|c|c|c|c|c|c|c|c|c|c|c|c|}
\hline Дисципліна & 1 & 2 & 3 & 4 & 5 & 6 & 7 & 8 & 9 & 10 & 11 & 12 & 13 & 14 & 15 & 16 & 17 & 18 & 19 & $\Sigma$ & $\bar{a}$ & $\bar{S}^{2}$ \\
\hline БЖД & 91 & 68 & 80 & 91 & 80 & 76 & 76 & 68 & 75 & 81 & 91 & 78 & 84 & 85 & 71 & 91 & 78 & 91 & 88 & 1543 & 81,2 & 58,8 \\
\hline ООП & 91 & 71 & 80 & 91 & 80 & 87 & 71 & 81 & 75 & 83 & 91 & 70 & 91 & 91 & 65 & 91 & 71 & 91 & 83 & 1554 & 81,8 & 76,2 \\
\hline
\end{tabular}

Таблиця 3 - Оцінки студентів 1-ої академічної групи під час вивчення спочатку БЖД, потім ООП в різних семестрах

\begin{tabular}{|c|c|c|c|c|c|c|c|c|c|c|c|c|c|c|c|c|c|c|}
\hline Дисципліна & 1 & 2 & 3 & 4 & 5 & 6 & 7 & 8 & 9 & 10 & 11 & 12 & 13 & 14 & 15 & $\Sigma$ & $\bar{a}$ & $\bar{S}^{2}$ \\
\hline БЖД & 61 & 83 & 62 & 60 & 64 & 61 & 83 & 61 & 91 & 61 & 91 & 61 & 61 & 83 & 61 & 1044 & 69,6 & 143,6 \\
\hline ООП & 64 & 76 & 61 & 60 & 65 & 74 & 76 & 60 & 91 & 61 & 90 & 62 & 63 & 92 & 66 & 1061 & 70,7 & 130,5 \\
\hline
\end{tabular}

Таблиця 4 - Оцінки студентів 2-ої академічної групи під час вивчення спочатку БЖД, потім ООП в різних семестрах

\begin{tabular}{|c|c|c|c|c|c|c|c|c|c|c|c|c|c|c|c|c|}
\hline Дисципліна & 1 & 2 & 3 & 4 & 5 & 6 & 7 & 8 & 9 & 10 & 11 & 12 & 13 & $\Sigma$ & $\bar{a}$ & $\bar{S}^{2}$ \\
\hline БЖД & 90 & 96 & 91 & 87 & 90 & 89 & 64 & 86 & 60 & 66 & 63 & 60 & 60 & 1002 & 77,1 & 197,9 \\
\hline ООП & 90 & 90 & 91 & 97 & 91 & 91 & 64 & 95 & 75 & 75 & 77 & 74 & 76 & 1086 & 83,5 & 98,6 \\
\hline
\end{tabular}

Таблиця 5 - Оцінки студентів 1-ої академічної групи під час вивчення спочатку ООП, потім БЖД в різних семестрах

\begin{tabular}{|c|c|c|c|c|c|c|c|c|c|c|c|c|c|c|c|}
\hline Дисципліна & 1 & 2 & 3 & 4 & 5 & 6 & 7 & 8 & 9 & 10 & 11 & 12 & $\Sigma$ & $\bar{a}$ & $\bar{S}^{2}$ \\
\hline БЖД & 75 & 60 & 61 & 60 & 60 & 77 & 60 & 64 & 60 & 65 & 60 & 64 & 766 & 63,8 & 33,0 \\
\hline ООП & 90 & 61 & 60 & 60 & 60 & 76 & 90 & 75 & 60 & 62 & 60 & 61 & 815 & 67,9 & 127,9 \\
\hline
\end{tabular}

Таблиця 6 - Оцінки студентів 2-ої академічної групи під час вивчення спочатку ООП, потім БЖД в різних семестрах

\begin{tabular}{|c|c|c|c|c|c|c|c|c|c|c|c|}
\hline Дисципліна & 1 & 2 & 3 & 4 & 5 & 6 & 7 & 8 & $\Sigma$ & $\bar{a}$ & $\bar{S}^{2}$ \\
\hline БЖД & 90 & 60 & 90 & 90 & 91 & 90 & 92 & 92 & 695 & 86,9 & 103,9 \\
\hline ООП & 62 & 60 & 91 & 91 & 75 & 75 & 90 & 90 & 634 & 79,3 & 151,4 \\
\hline
\end{tabular}

Для визначення існування залежності між двома рядами експериментальних даних скористаємось методом кореляції.

Коефіцієнт лінійної кореляції визначається за формулою

$$
r=\frac{\sum_{i=1}^{n}\left[\left(a_{1 i}-\overline{a_{1}}\right)\left(a_{2 i}-\overline{a_{2}}\right)\right]}{n \sqrt{\bar{S}_{1}^{2} \bar{S}_{2}^{2}}},(1)
$$

де $\bar{a}_{1}, \bar{a}_{2}-$ середні вибіркові значення величин, що порівнюються;

$a_{1 i}, a_{2 i}$ - часткові вибіркові значення цих величин;

$n$ - загальне число цих величин в рядах показників;

$\bar{S}_{1}^{2}, \bar{S}_{2}^{2}$ - дисперсія, відхилення цих величин від середніх значень. 
За Немовим (1998) про міцну кореляцію можна говорити тільки в тих випадках, якщо коефіцієнт кореляції є більшим за 0,7. Коефіцієнт кореляції в межах $0,5 \ldots 0,7$ прийнято вважати середнім, а якщо менше ніж 0,5 - слабким.

Порівняння та узагальнення результатів визначення оптимальної послідовності викладання дисциплін БЖД та ООП під час підготовки фахівців радіотехнічного профілю показано на рис. 1.

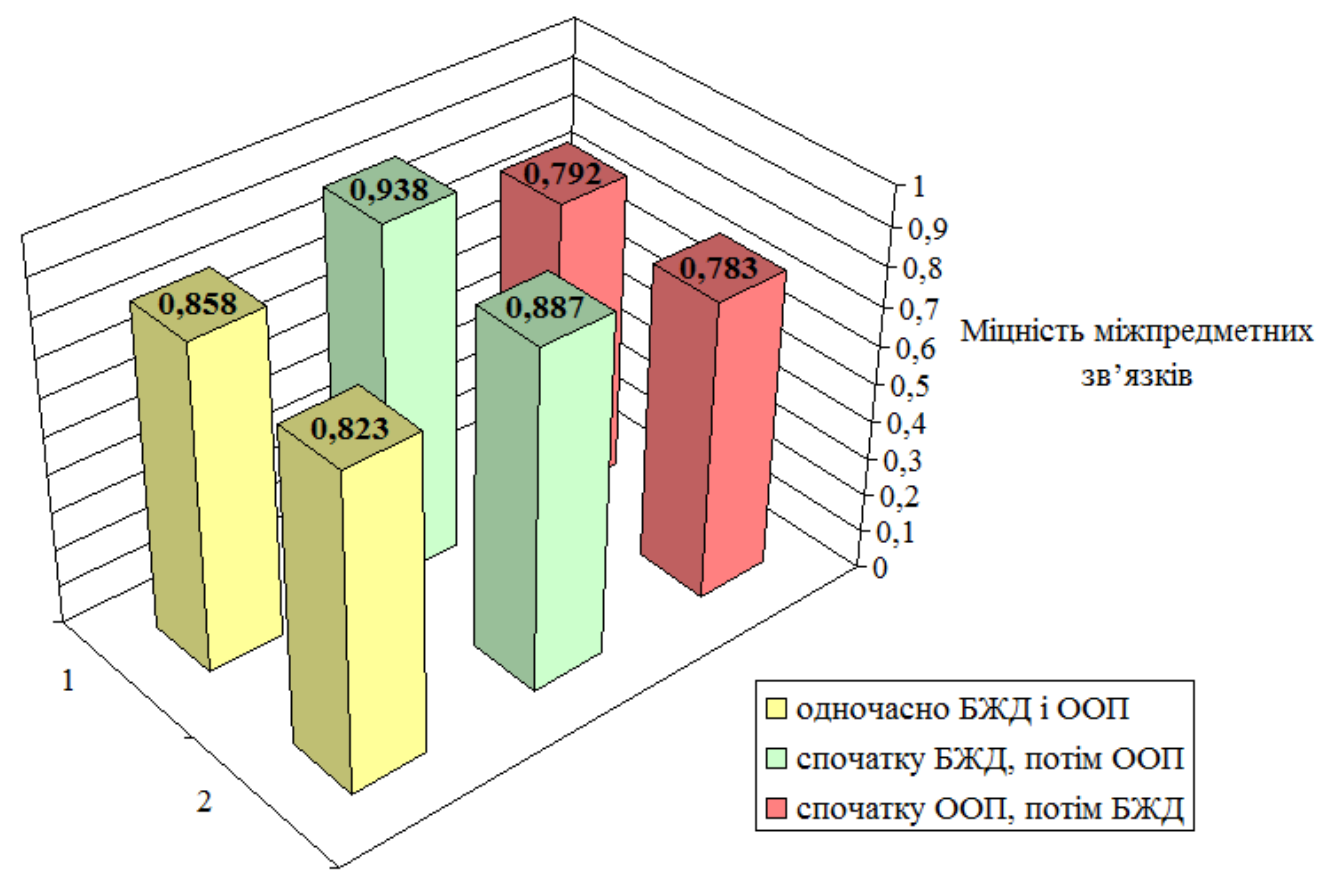

Рисунок 1 - Графічна інтерпретація результатів визначення оптимальної послідовності викладання дисциплін «Безпека життєдіяльності» та «Основи охорони праці» під час підготовки фахівців радіотехнічного профілю

Таким чином, на підставі зіставлення й порівняння даних, наведених на рис. 1, визначено міцні міжпредметні зв'язки в усіх трьох досліджуваних варіантах послідовності вивчення курсів БЖД та ООП, але найбільша міцність міжпредметних зв'язків досягається при вивченні спочатку курсу БЖД, а потім курсу ООП, а найменша - при вивченні спочатку курсу ООП, а потім курсу БЖД під час підготовки фахівців радіотехнічного профілю в академічних групах з різним рівнем успішності. Визначена оптимальна послідовність вивчення курсів БЖД та ООП підтверджується визначенням БЖД як дисципліни, наведеним Джигиреєм та Житецьким (2000, с. 4): «БЖД - це інтегрована дисципліна гуманітарно-технічного спрямування, яка узагальнює дані відповідної науковопрактичної діяльності, формує поняттєво-категорійний, теоретичний і методологічний апарат, необхідний для вивчення у подальшому охорони праці, захисту навколишнього середовища, цивільної оборони та інших дисциплін, що вивчають конкретні небезпеки і способи захисту від них».

\section{Висновки}

Таким чином, проведені дослідження свідчать, що за критерієм міцності міжпредметних зв'язків оптимальною послідовністю викладання дисциплін під час підготовки майбутніх фахівців радіотехнічного профілю є викладання спочатку безпеки життєдіяльності, а потім основ охорони праці в різних семестрах.

\section{СПИСОК ПОСИЛАНЬ}

Березюк, Л. Л., \& Березюк, О. В. (2018). Визначення рівня міжпредметних зв'язків у прочесі вивчення біології та географії майбутніми фахівиями у сфері коопераиії, Тези доповідей на IV Всеукраїнській науково-методичній конференції «Моє бачення шляхів удосконалення вивчення навчальної дисципліни, яку я викладаю». Вінниця: Коледж економіки і права Вінницького кооперативного інституту. 
Березюк, О. В. (2016). Застосування комп’ютерних технологій під час вивчення студентами дисциплін циклу безпеки життєдіяльності. Педагогіка безпеки, 1, 6-10.

Березюк, О. В. (2017а). Використання віртуального лабораторного стенда для проведення лабораторної роботи «Дослідження ефективності освітлення у виробничих приміщеннях». Педагогіка безпеки, 1, 35-39.

Березюк, О. В. (2017b). Міжпредметні зв'язки у процесі вивчення дисциплін циклу безпеки життєдіяльності майбутніми фахівцями радіотехнічного профілю. Педагогіка безпеки, 2, 21-26.

Березюк, О. В., \& Лемешев, М. С. (2011). Безпека життєдіяльності: навчальний посібник. Вінниця: ВНТУ.

Березюк, О. В., Лемешев, М. С., \& Віштак, І. В. (2014). Комп'ютерна програма для тестової перевірки рівня знань студентів, Тези науково-технічної конференції студентів, магістрів та аспірантів «Інформатика, управління та штучний інтелект». Харків: НТУ «ХПІ».

Березюк, О. В., Лемешев, М. С., Заюков, І. В., \& Королевська, С. В. (2017). Безпека життєдіяльності: практикум. Вінниця: ВНТУ.

Власов, К. П. (Ред.). (2002). Методы исследований и организащия экспериментов. Харьков: Гуманитарный центр.

Джигирей, В. С., \& Житецький, В. Ц. (2000). Безпека життєдіяльності: навчальний посібник (3-є, доповнене). Львів: Афіша.

Кобилянський, О. В. (2009). Міжпредметні зв’язки та особливості викладання безпеки життєдіяльності бакалаврам економічного спрямування. Вісник Вінницького політехнічного інститу$m y, 6,114-120$.

Кобилянський, О. В., Лемешев, М. С., \& Березюк, О. В. (2010). Основи охорони праці: навчальний посібник. Вінниця: ВНТУ.

Ковальчук, Л., \& Когут, І. (2008). Міжпредметні зв'язки у процесі вивчення хімії в загальноосвітній школі. Вісник Львівського університету. Серія педагогічна, 23, 80-89.

Кремечек, Г. А. (2006). Методологічні аспекти викладання безпеки життєдіяльності в навчальних закладах. Проблеми освіти, 49, 85-89.

Лемешев, М. С., \& Березюк, О. В. (2007). Основи охорони праці для фахівиів радіотехнічного профілю: навчальний посібник. Вінниця: ВНТУ.

Міністерство освіти і науки, молоді та спорту України. (2011a). Типова навчальна програма нормативної дисципліни «Безпека життєдіяльності» для вищих навчальних закладів. Київ: МОНMCY.

Міністерство освіти і науки, молоді та спорту України. (2011b). Типова навчальна програма нормативної дисципліни «Основи охорони пращі» для вищих навчальних закладів. Київ: МОНМСУ.

Немов, Р. С. (1998). Психология: учеб. для студ. высш. пед. учеб. завед. Психодиагностика. Введение в научное психологическое исследование с элементами математической статистики (Кн. 3). Москва: Гуманит. изд. центр ВЛАДОС.

Хом'юк, І. В. (2012). Система формування професійної мобільності майбутніх інженерів маминобудівної галузі. (Автореф. дис. докт. пед. наук). Національний університет біоресурсів і природокористування України, Київ.

Шукалюк, Г. П. (2016). Міжпредметні зв’язки на уроках охорони праці. Профтехосвіта, 4(88), 40-42.

\section{REFERENCES}

Bereziuk, L. L., \& Bereziuk, O. V. (2018). Vyznachennia rivnia mizhpredmetnykh zviazkiv u protsesi vyvchennia biolohii ta heohrafii maibutnimy fakhivtsiamy u sferi kooperatsii, Tezy dopovidei na IV Vseukrainskii naukovo-metodychnii konferentsii «Moie bachennia shliakhiv udoskonalennia vyvchennia navchalnoi dystsypliny, yaku ya vykladaiu». Vinnytsia: Koledzh ekonomiky i prava Vinnytskoho kooperatyvnoho instytutu.

Bereziuk, O. V. (2016). Zastosuvannia kompiuternykh tekhnolohii pid chas vyvchennia studentamy dystsyplin tsyklu bezpeky zhyttiediialnosti. Pedahohika bezpeky, 1, 6-10.

Bereziuk, O. V. (2017a). Vykorystannia virtualnoho laboratornoho stenda dlia provedennia laboratornoi roboty «Doslidzhennia efektyvnosti osvitlennia u vyrobnychykh prymishchenniakh». Pedahohika bezpeky, 1, 35-39.

Bereziuk, O. V. (2017b). Mizhpredmetni zviazky u protsesi vyvchennia dystsyplin tsyklu bezpeky zhyttiediialnosti maibutnimy fakhivtsiamy radiotekhnichnoho profiliu. Pedahohika bezpeky, 2, 21-26. 
Bereziuk, O. V., \& Lemeshev, M. S. (2011). Bezpeka zhyttiediialnosti: navchalnyi posibnyk. Vinnytsia: VNTU.

Bereziuk, O. V., Lemeshev, M. S., \& Vishtak, I. V. (2014). Kompiuterna prohrama dlia testovoi perevirky rivnia znan studentiv, Tezy naukovo-tekhnichnoi konferentsii studentiv, mahistriv ta aspirantiv «Informatyka, upravlinnia ta shtuchnyi intelekt». Kharkiv: NTU «KhPI».

Bereziuk, O. V., Lemeshev, M. S., Zaiukov, I. V., \& Korolevska, S. V. (2017). Bezpeka zhyttiediialnosti: praktykum. Vinnytsia: VNTU.

Dzhyhyrei, V. S., \& Zhytetskyi, V. Ts. (2000). Bezpeka zhyttiediialnosti: navchalnyi posibnyk (3-ye, dopovnene). Lviv: Afisha.

Khomiuk, I. V. (2012). Systema formuvannia profesiinoi mobilnosti maibutnikh inzheneriv mashynobudivnoi haluzi. (Avtoref. dys. dokt. ped. nauk). Natsionalnyi universytet bioresursiv i pryrodokorystuvannia Ukrainy, Kyiv.

Kobylianskyi, O. V. (2009). Mizhpredmetni zviazky ta osoblyvosti vykladannia bezpeky zhyttiediialnosti bakalavram ekonomichnoho spriamuvannia. Visnyk Vinnytskoho politekhnichnoho instytutu, 6, 114120.

Kobylianskyi, O. V., Lemeshev, M. S., \& Bereziuk, O. V. (2010). Osnovy okhorony pratsi: navchalnyi posibnyk. Vinnytsia: VNTU.

Kovalchuk, L., \& Kohut, I. (2008). Mizhpredmetni zviazky u protsesi vyvchennia khimii v zahalnoosvitnii shkoli. Visnyk Lvivskoho universytetu. Ceriia pedahohichna, 23, 80-89.

Kremechek, H. A. (2006). Metodolohichni aspekty vykladannia bezpeky zhyttiediialnosti v navchalnykh zakladakh. Problemy osvity, 49, 85-89.

Lemeshev, M. S., \& Bereziuk, O. V. (2007). Osnovy okhorony pratsi dlia fakhivtsiv radiotekhnichnoho profiliu: navchalnyi posibnyk. Vinnytsia: VNTU.

Ministerstvo osvity i nauky, molodi ta sportu Ukrainy. (2011a). Typova navchalna prohrama normatyvnoi dystsypliny «Bezpeka zhyttiediialnosti» dlia vyshchykh navchalnykh zakladiv. Kyiv: MONMSU.

Ministerstvo osvity i nauky, molodi ta sportu Ukrainy. (2011b). Typova navchalna prohrama normatyvnoi dystsypliny «Osnovy okhorony pratsi» dlia vyshchykh navchalnykh zakladiv. Kyiv: MONMSU.

Nemov, R. S. (1998). Psykholohyia. ucheb. dlia stud. vyssh. ped. ucheb. zaved. Psykhodyahnostyka. Vvedenye $v$ nauchnoe psykholohycheskoe yssledovanye s elementamy matematycheskoi statystyky (Kn. 3). Moskva: Humanyt. yzd. tsentr VLADOS.

Shukaliuk, H. P. (2016). Mizhpredmetni zviazky na urokakh okhorony pratsi. Proftekhosvita, 4(88), 40-42.

Vlasov, K. P. (Red.). (2002). Metody yssledovanyi y orhanyzatsyia eksperymentov. Kharkov: Humanytarnyi tsentr.

\section{Олег Березюк}

\section{Оптимізація міжпредметних зв'язків при формуванні компетенцій з безпеки у фахівців радіотехнічного профілю}

В роботі проведено дослідження з визначення оптимальної послідовності викладання дисциплін «Безпека життєдіяльності» та «Основи охорони праці» під час підготовки фахівців радіотехнічного профілю за критерієм міцності міжпредметних зв'язків вказаних дисциплін. Встановлено, що в різні навчальні роки послідовність викладання дисциплін Безпека життєдіяльності» та «Основи охорони праці» під час підготовки фахівців радіотехнічного профілю у Вінницькому національному технічному університеті була різною. Розглядались такі варіанти послідовності викладання дисциплін безпека життєдіяльності та основи охорони праці: вивчення дисциплін паралельно в одному семестрі; вивчення спочатку дисципліни «Безпека життєдіяльності», а в наступному семестрі - «Основи охорони праці»; вивчення спочатку дисципліни «Основи охорони праці», а в наступному семестрі - «Безпека життєдіяльності». Дослідження проводились окремо в двох академічних групах з різним рівнем успішності, де студенти отримали оцінки за 100-бальною шкалою 3 різних дисциплін. Порівняння дисперсій різних вибірок виконано за критерієм Фішера. Визначення міцності міжпредметних зв'язків проведено методом кореляції. Під час розрахунку коефіцієнта лінійної кореляції враховувались: середні та часткові вибіркові значення величин, що порівнюються, загальне число цих величин в рядах показників, дисперсії, відхилення цих величин від 
середніх значень. Порівняння однорідності різних вибірок та належності їх до однієї генеральної сукупності (майбутні фахівці радіотехнічного профілю) проводилось за критерієм Стьюдента. Наведено графічну інтерпретацію отриманих результатів. На підставі зіставлення даних визначено міцні міжпредметні зв'язки в усіх трьох досліджуваних варіантах послідовності вивчення курсів «Безпека життєдіяльності» та «Основи охорони праці». Встановлено, що за критерієм міцності міжпредметних зв'язків оптимальною послідовністю викладання дисциплін під час підготовки майбутніх фахівців радіотехнічного профілю є викладання спочатку безпеки життєдіяльності, а потім основ охорони праці. Визначена оптимальна послідовність вивчення курсів «Безпека життєдіяльності» та «Основи охорони праці» підтверджується визначенням безпеки життєдіяльності як дисципліни.

Ключові слова: послідовність викладання дисциплін; міжпредметні зв'язки; безпека життєдіяльності; основи охорони праці; коефіцієнт лінійної кореляції.

Олег Березюк - кандидат технічних наук, доцент, доцент кафедри безпеки життєдіяльності та педагогіки безпеки, Вінницький національний технічний університет, Вінниця, e-mail: berezyukoleg@i.ua

\section{Oleh Bereziuk}

\section{Optimization of Interdisciplinary Connections in Formation of Safety Competencies in the Radio Engineering Profile}

In this paper a study was conducted to determine the optimal sequence of teaching disciplines, the life safety and the bases of labor protection during the training of specialists in radio engineering according to the criterion of the strength of interdisciplinary connections of these disciplines. It was established that in the different academic years the sequence of teaching of disciplines the life safety and the bases of labor protection during the training of specialists in radio engineering at Vinnytsia National Technical University was different. The following variants of the sequence of teaching disciplines were considered: life safety and the bases of labor protection: the study of disciplines in parallel in one semester, the study of the initial discipline of life safety, and in the next semester - the bases of labor protection, the study of the discipline of the bases of labor protection, and in the next semester - the life safety. The research was conducted separately in two academic groups with different levels of success, where students received grades on a 100-point scale from different disciplines. The comparison of variances of different samples was performed according to Fisher's criterion. Determination of the strength of interdisciplinary connections is carried out by the correlation method. The calculation of the linear correlation coefficient took into account: the average and partial sample values of the comparable values, the total number of these values in the series of indicators, the variance, and the deviation of these values from the mean values. Homogeneity comparison of different samples and their belonging to one general population (future specialists of radio engineering profile) was conducted according to Student's criterion. Graphical interpretation of the obtained results is presented. On the basis of comparison and comparison of data, strong interdisciplinary connections are defined in all three studied variants of the sequence of studying the courses of life safety and the bases of labor protection. It was established that according to the criterion of the strength of interdisciplinary relations, the optimal sequence of teaching disciplines during the training of future specialists in the radio engineering profile is the teaching of the initial life safety, and then the bases of labor protection. The determined optimal sequence of studying the courses of life safety and the bases of labor protection is confirmed by the definition of life safety as a discipline.

Keywords: sequence of disciplines teaching; interdisciplinary connections; life safety; bases of labor protection; coefficient of linear correlation.

Oleh Bereziuk - Cand. Sc. (Eng.), Assistant Professor, Assistant Professor of the Chair Security of Life and Safety Pedagogic, Vinnytsia National Technical University, e-mail: berezyukoleg@i.ua 


\section{Олег Березюк}

\section{Оптимизация межпредметных связей при формировании компетенций по безопасности у специалистов радиотехнического профиля}

В работе проведено исследование по определению оптимальной последовательности преподавания дисциплин «Безопасность жизнедеятельности» и «Основы охраны труда» при подготовке специалистов радиотехнического профиля по критерию прочности межпредметных связей указанных дисциплин. Установлено, что в разные учебные года последовательность преподавания дисциплин «Безопасность жизнедеятельности» и «Основы охраны труда» при подготовке специалистов радиотехнического профиля в Винницком национальном техническом университете была разной. Рассматривались такие варианты последовательности преподавание дисциплин «Безопасность жизнедеятельности» и «Основы охраны труда»: изучение дисциплин параллельно в одном семестре; изучение сначала дисциплины «Безопасность жизнедеятельности», а в следующем семестре - «Основы охраны труда»; изучение сначала дисциплины «Основы охраны труда», а в следующем семестре - «Безопасность жизнедеятельности». Исследования проводились отдельно в двух академических группах с разным уровнем успеваемости, где студенты получили оценки по 100-балльной шкале по различным дисциплинам. Сравнение дисперсий различных выборок выполнено по критерию Фишера. Определение прочности межпредметных связей проведено методом корреляции. При расчёте коэффициента линейной корреляции учитывались: средние и частичные выборочные значения сравниваемых величин, общее число этих величин в рядах показателей, дисперсии, отклонение этих величин от средних значений. Сравнение однородности различных выборок и принадлежности их к одной генеральной совокупности (будущие специалисты радиотехнического профиля) проводилось по критерию Стьюдента. Приведена графическая интерпретация полученных результатов. На основании сопоставления данных, определены прочные межпредметные связи во всех трёх исследуемых вариантах последовательности изучение курсов «Безопасность жизнедеятельности» и «Основы охраны труда». Установлено, что по критерию прочности межпредметных связей оптимальной последовательностью преподавания дисциплин при подготовке будущих специалистов радиотехнического профиля является преподавание сначала безопасности жизнедеятельности, а затем основ охраны труда. Определённая оптимальная последовательность изучения курсов «Безопасность жизнедеятельности» и «Основы охраны труда» подтверждается определением безопасности жизнедеятельности как дисциплины.

Ключевые слова: последовательность преподавания дисциплин; межпредметные связи; безопасность жизнедеятельности; основы охраны труда; коэффициент линейной корреляции.

Олег Березюк - кандидат технических наук, доцент, доцент кафедри безопасности жизнедеятельности и педагогики безопасности, Винницкий национальный технический университет, Винница, e-mail: berezyukoleg@i.ua 